\title{
MEMPERINGATI MAULID NABI
}

\author{
NURUL INDARSIH
}

9173770410137

nurullindarsihh@gmail.com

1. Bentuk Kegiatan

> Memperingati Maulid Nabi Muhammad SAW.

2. Lokasi

> Aula Kampus Yapti Jeneponto.

3. Hari/Tanggal dan Waktu

> Kamis, 29 oktober 2020 pukul 10:00 - selesai.

4. Peserta yang Dilibatkan

> Ketua STIE dan STKIP Jeneponto

$>$ Dosen Pembimbing KKLP Yapti Jeneponto

$>$ Penceramah

> Mahasiswa KKLP Yapti Jeneponto

5. Alasan diadakannya

> Alasan diadakannya kegiatan ini adalah karena sudah tradisi sejak dulu melakukan acara peringatan Maulid Nabi Muhammad SAW. sebagai bentuk kecintaan kita kepada rosul.

6. Tujuan dan Manfaat

> Tujuan dan manfaat dilaksanakannya kegiatan ini di kampus yaitu untuk mempererat persaudaraan antar mahasiswa.

7. Deskripsi Kegiatan

> Kegiatan acara Maulid Nabi ini dilaksanakan di aula kampus, dan yang menjadi promotor kegiatan ini adalah mahasiswa KKLP angkatan XXII. Jadi setiap posko di semua kecamatan harus ikut berpartisipasi dalam kegiatan ini yaitu dengan cara membawa bakul hias tiap-tiap posko. 